\title{
KUVIKVÉDELEM EGY KÖZÉP-MAGYARORSZÁGI MEZŐGAZDASÁGI TERÜLETEN: KÖLTÉSI ADATOK ÉS A MESTERSÉGES FÉSZEKODVAK PARAMÉTEREINEK ÖSSZEFÜGGÉSEI
}

\author{
Hámori Dániel \\ Magyarországi Kuvik Oltalmi Egyesület, 1082 Budapest, Szőlő u. 86., 2/12. \\ Hungarian Little Owl Protecting Public Benefit Association, H-1082, Budapest, Szőlő u. 86., 2/12. \\ Soproni Egyetem, Vadgazdálkodási és Gerinces Állattani Intézet \\ 9400, Sopron, Bajcsy-Zs. u. 4 \\ e-mail: hamoridanielkoe@gmail.com
}

\begin{abstract}
HÁMORI D. (2017): LITTLE OWL CONSERVATION IN FARMLAND AREAS OF CENTRAL-HUNGARY: RELATIONSHIPS BETWEEN THE NESTING DATA AND NESTBOX PARAMETERS. Hungarian Small Game Bulletin 13: 187-199. http://dx.doi.org/10.17243/mavk.2017.187

The present study assesses the results of Little Owl surveys started in 2003 in Kiskunság, Mid-Hungary, using artificial nest boxes installed in the frame of a Little Owl conservation program. Parameters of occupied boxes and those not used by Little Owls were evaluated for the period 2006-2012 with regards to the successful reproduction rate. Between 2003 and 2016, a total of 635 Little Owl individuals were ringed. Total number of fledglings was 588. Occupancy and reproduction rate are mostly affected by the visibility of the nest box, the orientation of the hole and the distance from the typical habitats.
\end{abstract}

KULCSSZAVAK: kuvik, Athene noctua, denzitás, fészekodú-paraméterek, szaporodási siker, Közép-Magyarország

KEY WORDS: Little Owl, density, nestbox parameters, reproductive success, central Hungary

\section{BEVEZETÉS}

A kuvik költőhelyei hazánkban jellemzően tanyasi és gazdasági épületek padlásterei, a nagy kiterjedésű zárt erdőállományokat általában kerüli (SCHMIDT, 1998). Állománya számos európai országban csökkenő tendenciát mutat (CRAMP et al., 1985; VAN NIEUWENHUYSE et al., 2008; BiRdLife InTERNATIONAL, 2015). A Magyarországon élö törzsalak (Athene $n$. noctua) állományváltozási trendje pontosan nem ismert, a közölt párszámok csak szakértöi becsléseken alapulnak (GORMAN, 1995; MME NOMENCLATOR BIZOTTSÁG, 2008; ŚÁLEK et al., 2013). A feltételezett állomány 2000-4000 pár közötti lehet (HÁMORI \& CsORTOS, 2015). A nyugat-európában felismert állománycsökkenés révén a faj védelme és kutatása egyre nagyobb természetvédelmi jelentőséget kapott (GÉNOT, 1992; ANGELICI et al., 1997).

A mesterséges költőhely-biztosítás folyamatos terepi munkát igénylő, költségigényes természetvédelmi tevékenység, amelyet széles körben alkalmaznak a természetes költöüregekben költő madárfajok esetében (NEWTON, 1994; OLAH et al., 2014). Az odúban költő fajok védelme eredményes lehet, ha az élőhely-összetétel megfelelő és vannak alkalmas táplálkozó területek is (KISS et al., 2016). Ez a tevékenység hozzájárul az adott faj populációjának erősítéséhez (BOLTON et al., 2004; PRIDDEL et al., 2006). A csekély költési 
lehetőséggel rendelkező élőhelyeken a természetes odvak nélkül költőhelyhiány alakul ki, ami sok odúban költő faj populációjának csökkenése mögött áll (SUTHERLAND et al., 2004). A kuvik ökológiáját igen részletesen tanulmányozták, így a természetes és antropogén fészkelőhelyek kiválasztását és az élőhelyi feltételeket is (SCHWARZENBERG, 1970; SCHÖNN et al., 1991; EXO, 1992; VAN NIEUWEHUYSE et al., 2001). A kuvik kihasznál minden potenciális költőhelyet, ahol opportunista táplálkozása megvalósulhat, így amennyiben rendelkezésre áll megfelelö természetes költöüreg, úgy annak elfoglalására törekszik (VAN NIEUWENHUYSE et al., 2008). Egyes szerzők rámutattak arra, hogy a kuvik állománycsökkenések a természetes költési lehetőségek szükülésével összefüggésben állnak (GÉNOT \& VAN NIEUWENHUYSE, 2002; THORUP et al., 2010). A másodlagos odúköltő, fészket nem építő kuvik jelentősen függ a rendelkezésre álló költőhelyek mennyiségétől. A mesterséges fészekodvak kihelyezését a kuvik költőállományának növelésére Európa több területén is sikeresen alkalmazták (KIRCHBERGER, 1988; LECOMTE et al., 2001; LEIGH, 2001), de ezzel összefüggésben az odúk paramétereit, valamint a faj szempontjából fontos élőhelyi feltételeket és a projektek populáció-dinamikai hatásait csak néhány esetben vizsgálták (GOTTSCHALK et al., 2011). A hasonló konzervációbiológiai tevékenységek esetén elsődleges szempont kell legyen, hogy a kiindulási pont és végcél közötti stádiumok elemzése ne maradjon el (STANDOVÁR, 2001). A foglalási és reprodukciós adatok elemzése fontos, hiszen könnyen elképzelhetö, hogy a nem megfelelő élőhelyekre telepített, mesterségesen biztosított költőhelyen a faj reprodukciós sikere alacsonyabb értékhez vezet, így azok hosszú távon ökológiai csapdát jelenthetnek (KLEIN et al., 2007). Emellett vizsgálnunk kell az odúk kihelyezésének paramétereit is, mivel ezek befolyásolhatják a foglaltságot és a költési sikert (LOWTHER, 2012; LAMBRECHTS et al., 2012).

\section{ANYAG ÉS MÓDSZER}

A vizsgálati terület (70.000 ha) a Kiskunsági Nemzeti Park északi területén, BácsKiskun és Pest megye területén, Budapesttől délkelet irányban 40 km-re a Kiskunság északi részén terül el ( $\mathrm{N}$ 47.068106, E 19.222133) (1. térkép). A Felső-Kiskunság átlagos tengerszint feletti magassága 84 méter, a védett természeti területek aránya $15,7 \%$. Ez a terület - amely a magyarországi kuvikpopuláció egyik minta-, és egyben magterületének tekinthető - egykor az igazi erdőspuszták birodalma volt, de a századforduló óta a DunaTisza közén nagyarányú mezőgazdasági fejlődés indult meg, ami a folyószabályozások lezárultával magával hozta a terület ősi jellegének drasztikus megváltoztatását (RAKONCZAY, 2001). A kiszárított és müvelésbe vont területek nagy része ma korszerüen müvelt mezö- és kertgazdasági terület. A gyepfelületek jelentős részét az utókor számára a legeltetés és a kaszálás mentette meg, viszont a kuvik számára preferált élőhelyeken folyamatos az állattartás visszaszorulása és a tanyavilág megszünése. A magyarországi alföldi költőhelyek jelentős része a 90'-es évek óta folyamatosan átalakul, a fiatal, telepített erdőállományok fészkelésre alkalmatlanok, az antropogén költőhelyek (tanyasi, mezőgazdasági létesítmények) helyére sok esetben új, modern, költésre alkalmatlan épületeket létesítenek vagy a meglévők elhagyatottá válnak és idővel összeomlanak (HÁMORI, 2016). Az alföldi antropogén költőhelyek veszélyeztető tényezői közül a legfontosabbak a felújítási munkák, a nyestek (Martes foina) térfoglalása (KALOTÁs, 1987), továbbá a peszticidek, valamint a másodlagos mérgező hatású rágcsálóirtó-szerek használata.

Az első odúkihelyezések 2003-ban kezdődtek meg. A telepítési koncepció szerint olyan táplálkozó- és élőhelyekre történtek az odúkihelyezések, ahol az alkalmas költőhelyek hiánya, valamint az épületek (mint potenciális antropogén fészkelőhelyek) szerkezetén belül 
és annak közvetlen környezetében regisztrált veszélyeztető tényezők miatt célszerü volt a mesterséges odúk kihelyezése. A használt odúk szerkezete HARASZTHY (1982) leírásának felel meg, kisebb müszaki fejlesztésekkel (HÁMORI, 2012). A berepülő nyílás $80 \mathrm{~mm}$-es, az odú hossza $120 \mathrm{~cm}$. A külső nádborítás alatt vízzáró réteg, az elülső lap mögött egy terelő is található az árnyékolás és a nyest elleni védelem céljából (1. ábra). A müszakilag egységes kivitelü odúk $(25 \times 25 \times 120 \mathrm{~cm})$ telepítése minden évben - a területet új odúkkal bővítve, és a szükséges cseréket, felújításokat elvégezve - a kirepülést követő időszakban történt (augusztus-március). Az odúkat többségében fára rögzítettük (89\%). A teljes odúpark ellenörzésére 2003-2016 között a kotlási és fiókanevelési időszakban, valamint a kirepülést követően is minden évben sor került. A költési-, reprodukciós-, gyürüzési és biometriai adatfelvétel mellett a terepi munka során az egyéb okból esetlegesen tönkrement költéseket is (pl. predáció, szülők pusztulása, odú eltünése) rögzítettük. Egy odút akkor tekintettünk foglaltnak, ha tojásokat vagy fiókákat találtunk a fészekben.

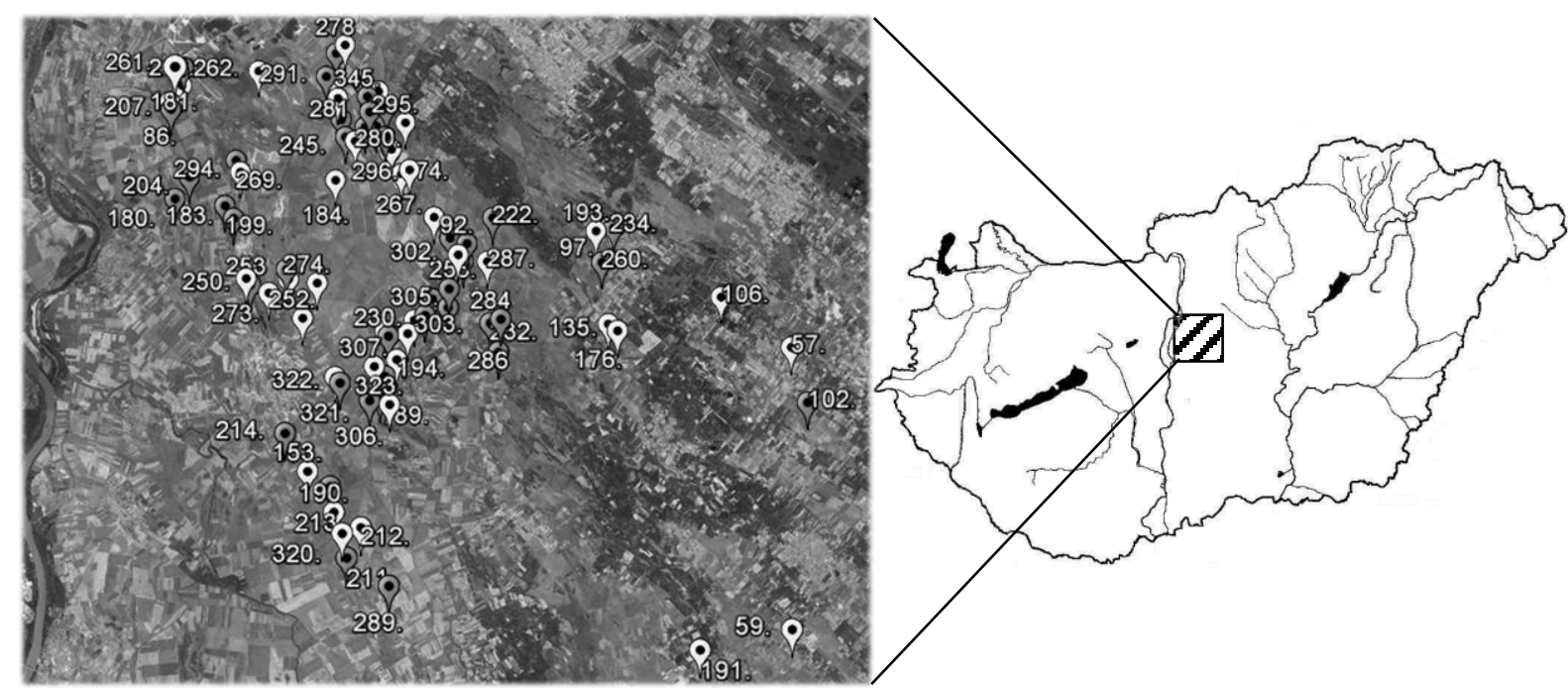

1. térkép: A felső-kiskunsági terület és az elemzett, fészkelésre alkalmas odúk elhelyezkedése Map 1: The Upper Kiskunság and the location of analyzed nests suitable for breeding

Az odúkihelyezések során a faj ökológiai és költésbiológiai jellemzői (MıKKOLA, 1983; VAN NIEUWENHUYSE et al., 2008) alapján a következő paramétereket vettük fel: kihelyezési magasság $(\mathrm{m})$; berepülő nyílás irányzéka $\left(^{\circ}\right)$; fafaj, amelyre az odú került; rögzítési helyzet (törzsre erösített, vízszintes oldalágra lógatva); láthatósági jellemzők (külön álló faegyed, facsoport széle, fasor széle). Az odútól mérve rögzítettük az egyes preferált élőhelyi kategóriák legközelebbi mért távolságait: legalább háztáji állattartást folytató tanyasi/mezőgazdasági épület $(\mathrm{m})$; erdőterület (min. $3 \mathrm{ha})(\mathrm{m})$; legeltetett gyepterület (min. 1 ha) (m); szőlö/gyümölcsös (min. 0,5 ha) (m); aszfaltozott közút (m). A vizsgált odútól mért legközelebbi élöhelyi távolságokat a CORINE felszínborítás (CORINE 50 Land Cover 2006) térképek, valamint a már rendelkezésre álló légifelvételek térinformatikai mérései segítségével határoztuk meg. E mellett a felmérési adatok rögzítése során meghatározásra került a foglalási ráta (\%), a kelési siker (\%), valamint a szaporodási siker (fiókaszám-átlag). Utóbbit az odú fészkelésre alkalmas évei, a tojásszám, valamint a sikeresen kirepült fiókaszám alapján képeztük. Sikeres kirepülésként értelmeztük azon fiókák egyedszámát, amelyek ellenőrzéskor legalább a 21 napos kort elérték. Az adatok kiértékelése Microsoft Excel 2016 programmal történt. 


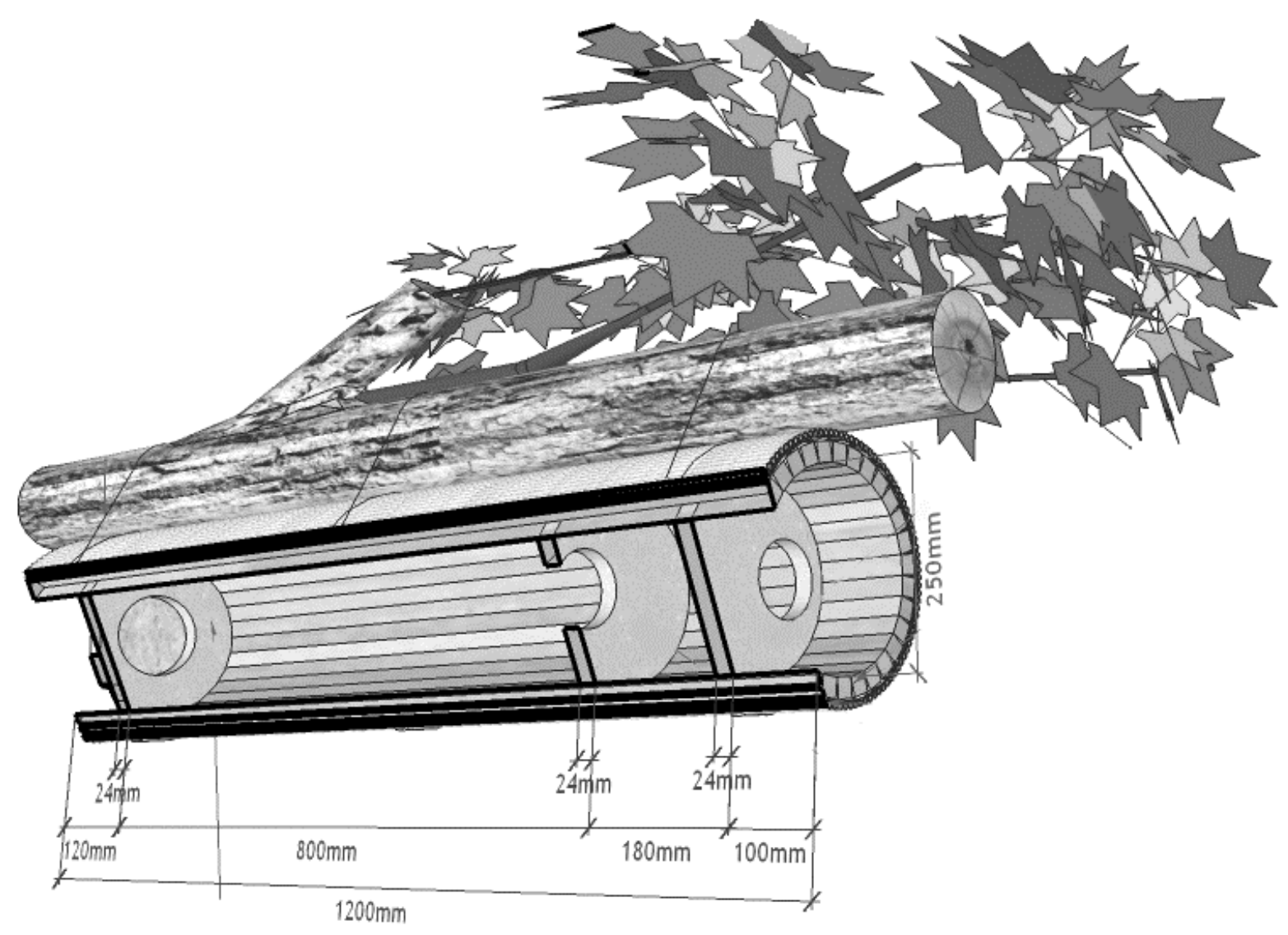

1. ábra: A Kiskunságban alkalmazott kuvikodú szerkezeti rajza

Figure 1: The structural scheme of the Little Owl nest box used in Kiskunság

A területre kihelyezett teljes odúparkra vonatkozólag megtörtént a 2003-2016-os költési eredmények, valamint az ismert minimális költőpár-számok alapján a denzitás-értékek összegzése. A tanulmány fö elemzéséhez a rendelkezésre álló adatok több szempont szerint is szürésre kerültek. Az első odúfoglalások csak 2005-ben történtek a területen. A foglalási arány jelentős mértékben csak 2012-től emelkedett, így az odúkhoz tartozó paramétereket elemző vizsgálat csak a 2012-2016 közötti időszakban, a fára kihelyezett fészkelésre alkalmas odúkat tárgyalja. Ezen odúk körzetében a kuvik otthonterület skálája $(284 \mathrm{~m})$ szerint lehatároltuk a revírterületeket (Š́́LEK et al., 2012). Szürésre kerültek azok a költésre elfoglalt odúk, ahol ugyanazon évben a költőhelyi skálák átfedték egymást $(\mathrm{N}=44)$. Ez azért volt fontos, hogy két azonos élőhelyi feltétellel rendelkező revír ne kerüljön be a kiértékelésbe. A foglalt odúk közötti legközelebbi mért távolság így 618 méter volt. A foglalatlan odúkat random módon választottuk ki, majd kizártuk azokat, amelyek a foglalt odúk költőhelyi skáláján belül helyezkedtek el, valamint amelyekben akár egy alkalommal is történt más madárfaj által foglalás/költés. A helyes számítások érdekében mind a foglalt, mind a foglalatlan odúk esetében figyelembe vettük a vizsgált időszakban a fészkelésre alkalmas évek számát (min. 1; max. 5). Az összehasonlító elemzés során meghatározásra került a válogatott foglalt odúk átlagos szaporodási sikere. Ez alapján a foglalt odúkat alacsony-, valamint magas szaporodási rátával rendelkező csoportba rendeztük, ahol a felvett paramétereket a fészkelésre alkalmas évek alapján súlyozottan értékeltük. 


\section{EREDMÉNYEK ÉS MEGVITATÁS}

Az előzetes hívóhangos állománybecslési módszertan (EXO \& HENNES, 1980) szerint végzett állományfelmérés alapján 2003-ban a kutatási terület minimális denzitása 0,098 pár/100 ha volt (HÁMORI, 2009). A 2012-2016 közötti felmérések során az odúinkban zajló költések mellett a területen regisztráltuk az antropogén költőhelyek ismert fészkeléseit is. Ez alapján leolvasható (2. ábra), hogy a 2003-ban becsült értékhez képest a felső-kiskunsági kuvikpopuláció ismert minimális költőpár-száma 2014-ben valamelyest már meghaladta a 2003-as becslést (0,098 pár/ha), majd ezt követően folyamatosan emelkedett. 2016-ra (0,161 pár/ha) a költőállomány nagysága 2003-hoz képest $64 \%$-al emelkedett. 2014-től - a sikeresen kirepült, ismert minimális fiókaszámok alapján - denzitás-növekedés feltételezhetö. Jelen program eredményei igazolják, hogy a kuvik mesterséges megtelepítése képes ellensúlyozni a természetes költőüreg-hiányt, mérsékelni az antropogén veszélyeztető tényezőket, valamint bizonyítja, hogy az alföldi élőhelyek a kuvik élőhelyi- és táplálkozásbiológiai preferenciáinak jórészt megfelelnek. Elsősorban a fészkelési lehetőségek kis száma szorítja vissza a populáció-dinamikai lehetőségeket.

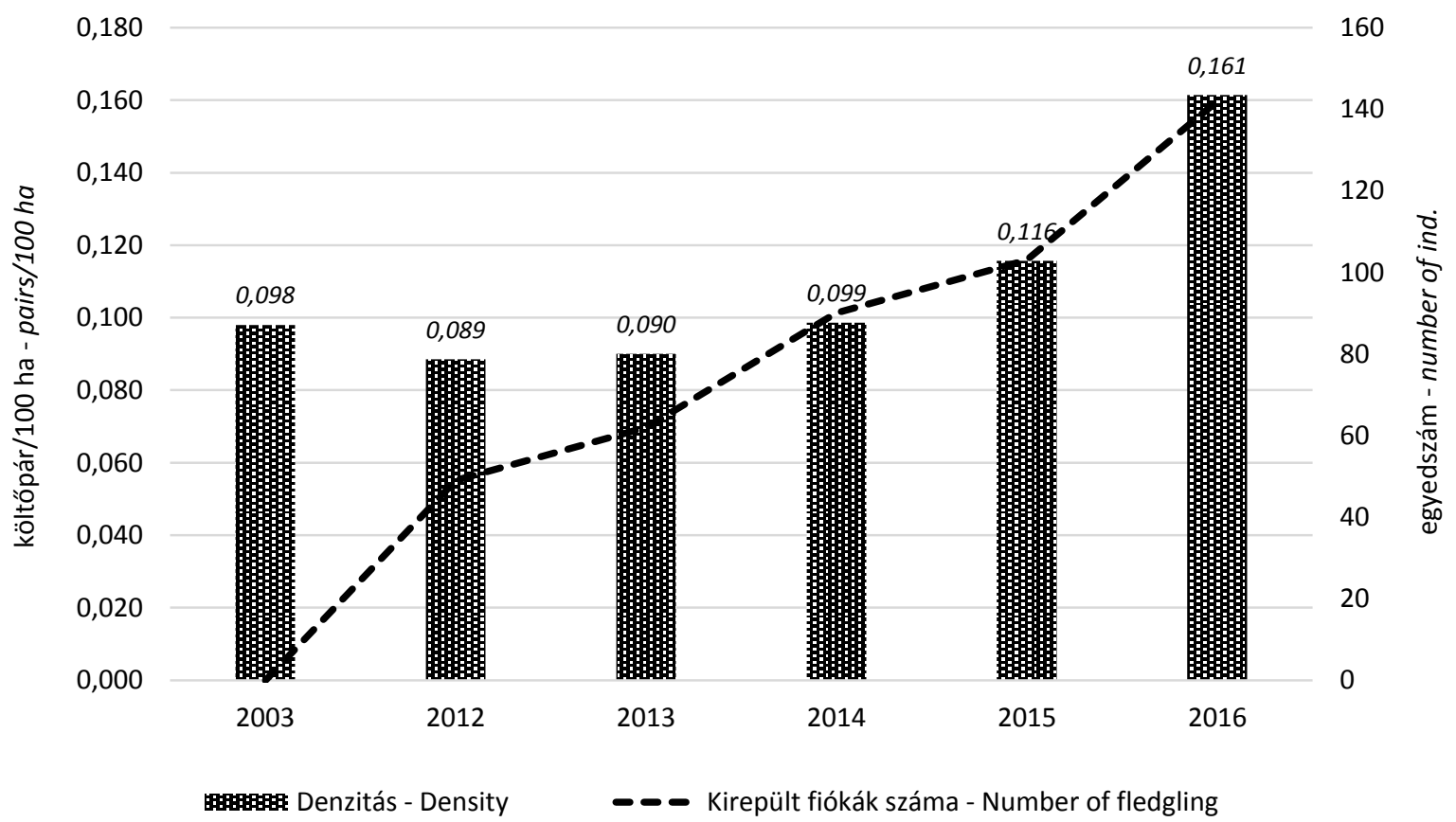

\section{2. ábra: A Felső-Kiskunság kuvikállományának denzitás-értékei a becsült és ismert minimális} párszámok tükrében $(2003,2012-2016)$

Figure 2: Little Owl population density values of the Upper Kiskunság based on the estimated and known pairs (2003, 2012-2016)

A 2003-tól telepített odúkban elsőként csak 2005-ben voltak megtelepedések és sikeres költések. Ezt követően az odúszámot is évröl-évre növelve a foglalások és a sikeres költések száma lassú ütemben növekedett. A sikeresen kirepült fiókaszám-átlagok 3,77 (2012) és 7 (2011) közöttiek. A foglalási ráta látványos emelkedése csak 2011-től érzékelhető jelentősen (3. ábra). Amennyiben az adott évben fészkelési lehetőséget biztosító odúszámok tükrében vizsgáljuk a foglaltságot, úgy látható, hogy 2013-tól a rendelkezésre álló odúszámnövekedéshez képest jóval erőteljesebb tendenciát képvisel a foglaltsági arány növekedése. Ez alapján jelentős odúszám-növelés nélkül is további foglalási arány-növekedés prognosztizálható a következö évekre. Fontos megjegyezni viszont, hogy 2013-tól az egy 
odúra vonatkoztatott átlagos fiókaszám $(5,17)$ enyhén csökkenő tendenciát mutat $(3,94)$. Erre figyelemmel kell lenni, hiszen adott területen a mesterséges fészekodú-többlet nagyobb kuviksürüség esetén magasabb fokú intraspecifikus konkurenciához vezethet, amely az adott élőhelyen esetleges táplálékhiányt, alacsony szaporodási sikert eredményezhet (NEWTON, 1994; MÄND et al., 2005). A sikertelen költések számát tekintve nincs jelentős eltérés, a felmérési években 0-5 alkalommal hiúsult meg a fészkelés.

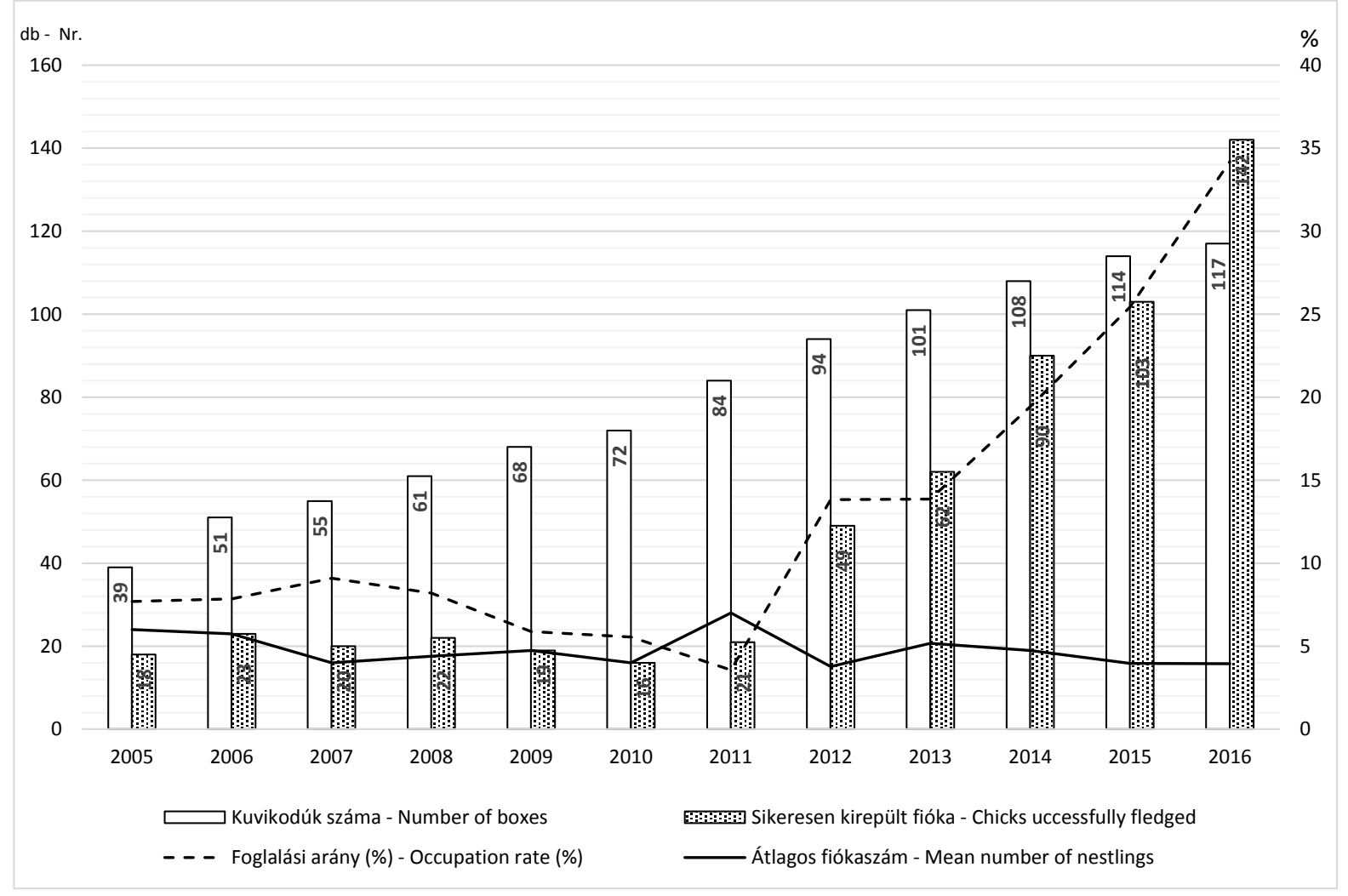

3. ábra: Költési eredmények a fészkelésre alkalmas odúszámok tükrében a Kiskunságban (2005-2016)

Figure 3: Hatching results in light of the number of nests suitable for breeding in Kiskunság (2005-2016)

A 2012-2016 közötti időszakban a legalább egy alkalommal költésre elfoglalt otthonterület skála szerint szürt - odúk átlagos szaporodási siker-értéke 3,8 (N=44). Németországi és holland területeken megállapították a kuvikpopuláció állományának stabilitását biztosító minimális szaporodási siker értékét, amelyet 2,35 fióka/költőpár-számban határoztak meg (EXO \& HENNES, 1980). Egy Frankfurthoz közeli élöhelyre telepített kuvikodúk költési eredményeit vizsgáló, három évet összegző tanulmányban GoTTSCHALK et al. (2011) 2,21-es szaporodási rátát állapítottak meg. A vizsgált kiskunsági kuvikodúk 3,8-as szaporodási rátája tehát az említett irodalmi adatok alapján igen magas értéket képvisel. Emiatt a foglalt odúkon belül nem az állomány-stabilitást jelentő szakirodalmi 2,35-ös ráta, hanem a kapott 3,8-as ráta-átlag alapján történt meg az odúk elkülönítése. A 3,8 alatti értéket képviselő csoportba az alacsony szaporodási rátát mutató odúk $(\mathrm{N}=21)$, míg az e felettibe a magas szaporodási rátát mutató odúk $(\mathrm{N}=23)$ kerültek. Az odúkhoz tartozó összegzett és átlagolt foglaltsági, kelési-, és szaporodási siker értékek ez alapján kerültek kiértékelésre (4. ábra). A magas szaporodási siker kategóriába kerülő odúk szaporodási siker arányának átlaga meglepően magas $(4,63)$, de még az alacsonyabb szaporodási sikert képviselők átlaga 
is magasabb (2,88), mint az EXO \& HENNES (1980) alapján megállapított állomány-stabilitási szaporodási ráta (2,35). Meglepő módon a két elkülönített odúcsoport között az elfoglaltsági arány, valamint a kelési siker tekintetében nincs jelentős különbség. Az eltérő szaporodási siker átlagok így valószínüleg más élőhelyi tényezőkkel magyarázhatók.

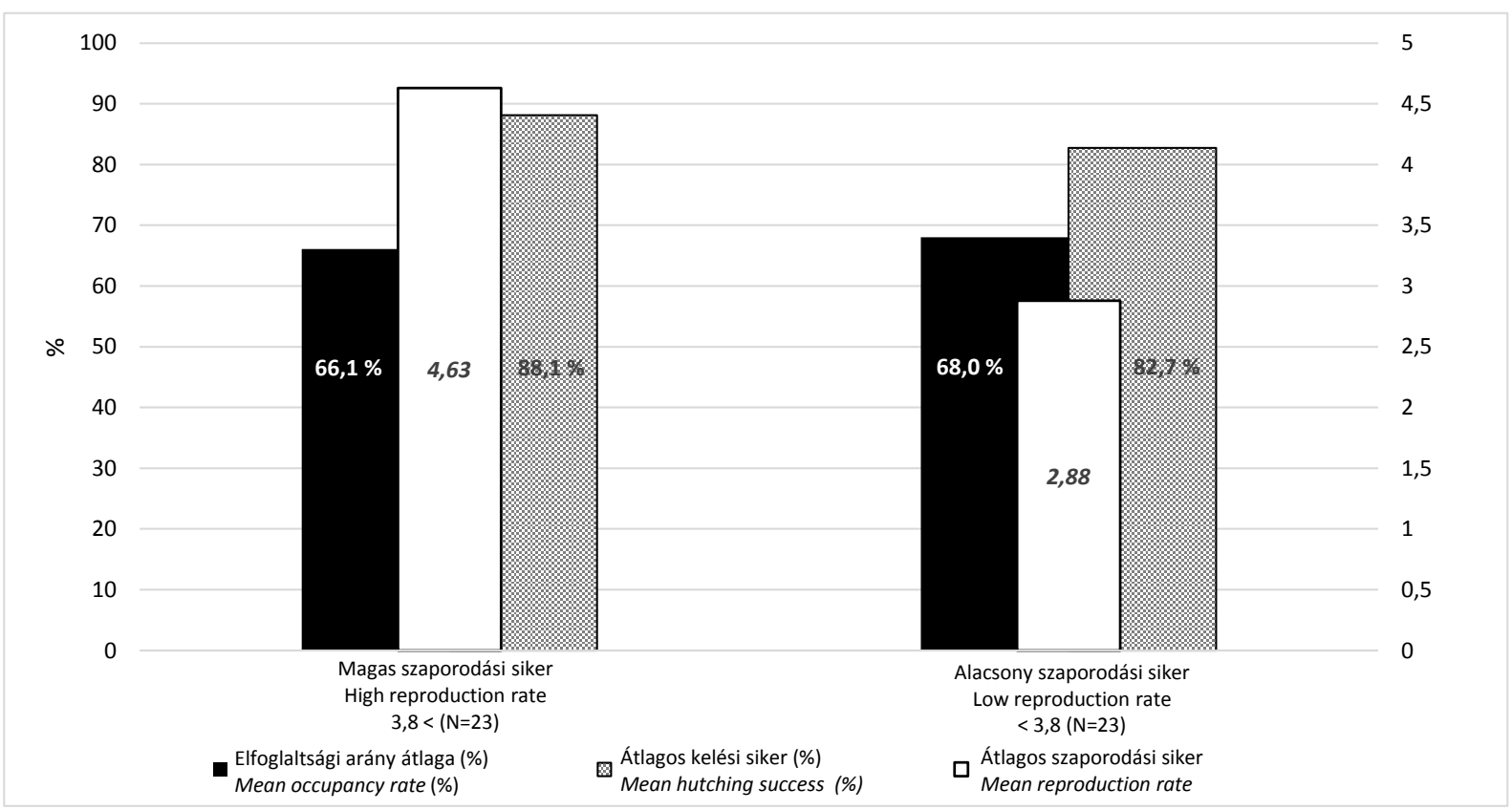

4. ábra: Magas és alacsony szaporodási sikerrel rendelkező odúk foglaltságának és reprodukciós adatainak összevetése (2012-2016)

Figure 4: Comparison of occupancy and reproduction data in nests with high and low reproductive success (2012-2016)

A faj ökológiája szempontjából fontos élöhelyek legközelebbi térbeli távolsága, valamint az odúk kihelyezési magassága a szaporodási siker kategóriáknak megfelelően a foglalt és a foglalatlan odúk esetében is mérésre került. Az eredmények a 100\%-ig halmozott diagram alapján értelmezhetőek (5. ábra). Az odúk átlagos talajszinttől mért kihelyezési magasságai között nincs jelentős különbség. A gyakorlatban alkalmazott, 2-6 m közötti kihelyezési magasságú odúk mindegyikében volt költés, illetve tartós foglalás. Svájcban kimutatták (JuILLARD, 1989), hogy a kuvikpopuláció 1950 és 1985 között mutatkozó drasztikus csökkenése a kedvezö élőhelyek szükülése, valamint az idős gyümölcsfák - mint természetes költőhelyet biztosító természeti értékek - kitermelése miatt következett be, így fontos volt figyelembe venni a gyümölcsösök térbeli távolságait. GoTTSCHALK et al. (2011) vizsgálata szerint a fészkelésre elfoglalt kuvikodúk az erdőktől átlagosan $761 \mathrm{~m}$-re, a gyümölcsösöktől átlagosan 53 m-re helyezkedtek el (tengerszint feletti magasság $164 \mathrm{~m}$ ). A magas foglalási rátájú kuvikodúk általában a gyümölcsösöktől valamint az erdőterületektől távolabb helyezkedtek el, a foglaltság tükrében ezek voltak a legerősebb prediktor-változók (GOTTSCHALK et al., 2011). A gyümölcsös területek mérései alapján ez a kiskunsági magas szaporodási siker értékkel rendelkező odúk esetében is igaz, hiszen ezen odúk helyezkedtek el a legtávolabb a gyümölcsösöktől $(2971 \mathrm{~m})$. Az erdők távolságának tekintetében is igazolást nyert, hogy az erdőktől távolabb kihelyezett kuvikodúk esetében magasabb szaporodási siker várható (1036 m). TOMÉ et al. (2004) megállapította, hogy a konkurens ragadozómadarak 
hatással vannak a faj fészkelőhely-választására és szaporodási sikerére (ZUBEROGOITIA et al., 2005). SCHÖNN et al. (1991) beszámolt arról, hogy a macskabagoly (Strix aluco) kiszoríthatja a magasabb erdősültségi arányú élőhelyekről a kuvikot. Ezzel kapcsolatban a felső-kiskunsági területeken további elemzések szükségesek a macskabagoly tényleges előfordulása és állománya kapcsán. Az aszfaltozott közutak távolsága szoros összefüggésben áll az elütött kuvikok számával (GÉNOT, 1991; FRIAS, 1999). A közúti forgalom a sikeresen kirepült fiatal egyedekre jelent nagy veszélyt kezdetleges röpképességük idején. Bár a közeli úthálózat a faj tekintetében ökológiai csapdát jelent (ZABALA et al., 2006), ennek ellenére a kuvik költőhelyei általában a forgalmas utakhoz közel helyezkednek el (ROBERTSON \& HUTTO, 2006). Ez első sorban a táplálkozási szokásokkal lehet összefüggésben, mert a megvilágított közutak több rovar-, és kisemlős zsákmányfajt is oda koncentrálnak éjszaka. A közutaktól mért távolságok átlaga a magas szaporodási sikerrel rendelkező odúk esetében a legkisebb (564 m). Eredményeink alapján így kijelenthető, hogy a kuvik magas toleranciaspektrumú az aszfaltozott közutak zavaró tényezőivel szemben, valamint a területen a veszélyeztető tényezők ellenére, táplálkozásbiológiai szempontból preferálja ezek közelségét.

Nem vizsgálták még, hogy a kuvik egy adott élöhelyen elsősorban milyen állattartási módokat és hozzá kapcsolódó élőhelyeket részesít előnyben (VAN NIEUWENHUYSE et al., 2008). A kuvik, mint nagy alkalmazkodó képességgel rendelkező faj, napjainkra az emberi létesítményekbe kényszerült, költőhelyei az alföldön jellemzően tanyasi és gazdasági épületek padlásterei (SCHMIDT 1998). A 2015-ös kiskunsági költési eredmények alapján a kuvikok elsősorban a juhtelepekhez és hozzá tartozó gyepterületekhez (57\%) kötődnek (HÁMORI, 2016). Az egyes élőhelytípusok térbeli távolságának vizsgálata során ezen alföldi élőhely tekintetében így fontos volt a szakirodalmi prediktorok mellett megvizsgálni a legeltetett gyepterületek, valamint a legalább háztáji állattartást folytató tanyasi/gazdasági épületek odútól mért legközelebbi távolságát. A kapott adatok a feltételezéstől - miszerint a magas szaporodási sikerü odúk átlagtávolsága lesz a legközelebbi az épületekhez és a legeltetett gyepterületekhez - jelentősen eltértek. Az adatok szerint a várható magas szaporodási siker érdekében az odúkat a gyepterületekről átlagosan 106, a tanyasi/gazdasági épületektől 116 méterre érdemes kihelyezni. Ettől közelebbi távolságok esetén alacsonyabb szaporodási siker (gyepterület $31 \mathrm{~m}$ ), jóval nagyobb távolságok esetén $(293 \mathrm{~m}, 395 \mathrm{~m})$ pedig potenciális foglalatlanság prognosztizálható. Ezek alapján kijelenthetö, hogy a kuvikok revír-területükön belül azt preferálják, ha a költőodútól mérve a fészkelési skálán belül (142 m, ŠÁLEK et al., 2012) elérhető a két vizsgált élőhelytípus.

Az odúkhoz tartozó paraméterek vizsgálati eredményei közül jelentős különbség csak az odú láthatósága, valamint egyes fafajokra helyezett odúk foglalatlansága esetében adódott (6. ábra). A facsoportok szélére helyezett odúk 49\%-át egyáltalán nem foglalták el költésre a kuvikok. A fehér eperre (Morus alba), füz-fajokra (Salix spp.), valamint a lepényfákra (Gleditsia triacanthos) helyezett odúkat a kuvikok egy esetben sem foglalták el $(\mathrm{N}=7)$. A rögzítési helyzet tekintetében nincs eltérés a 3 elemzett kategória között. A vízszintes oldalágra lógatva rögzített odúk foglaltsági arányai közel megegyeztek a fa törzsére rögzített odúkéval. Az odúk berepülő nyílás irányzékának megoszlása is mind három esetben hasonló megoszlást mutat, így az odúk kihelyezésekor az irányzék figyelembevétele mellőzhető. 


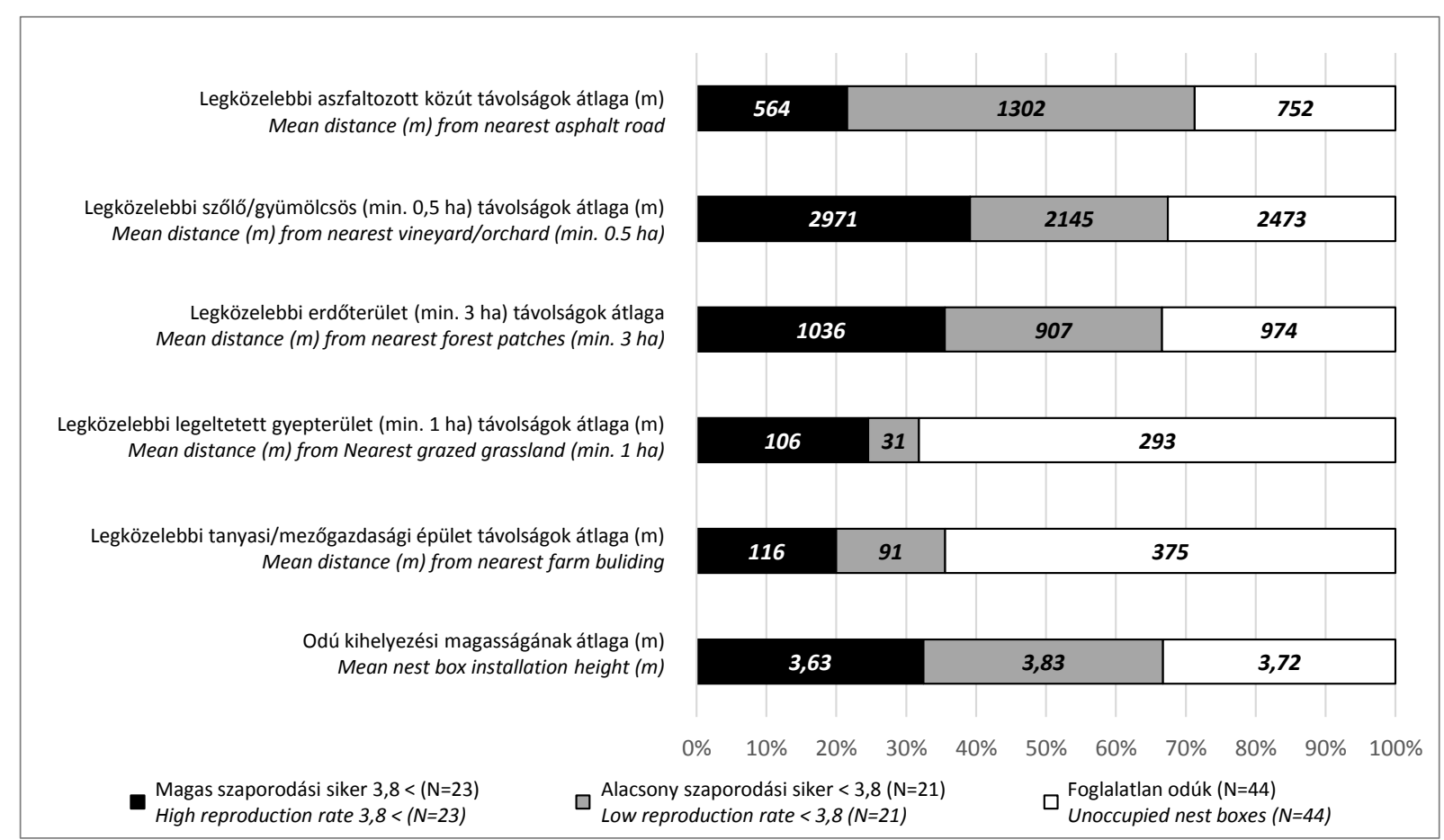

5. ábra: Vizsgált élőhelytípusok odútól mért legközelebbi távolságainak összevetése

Figure 5: Comparison of the measured distance between the nest and the nearest investigated habitat types

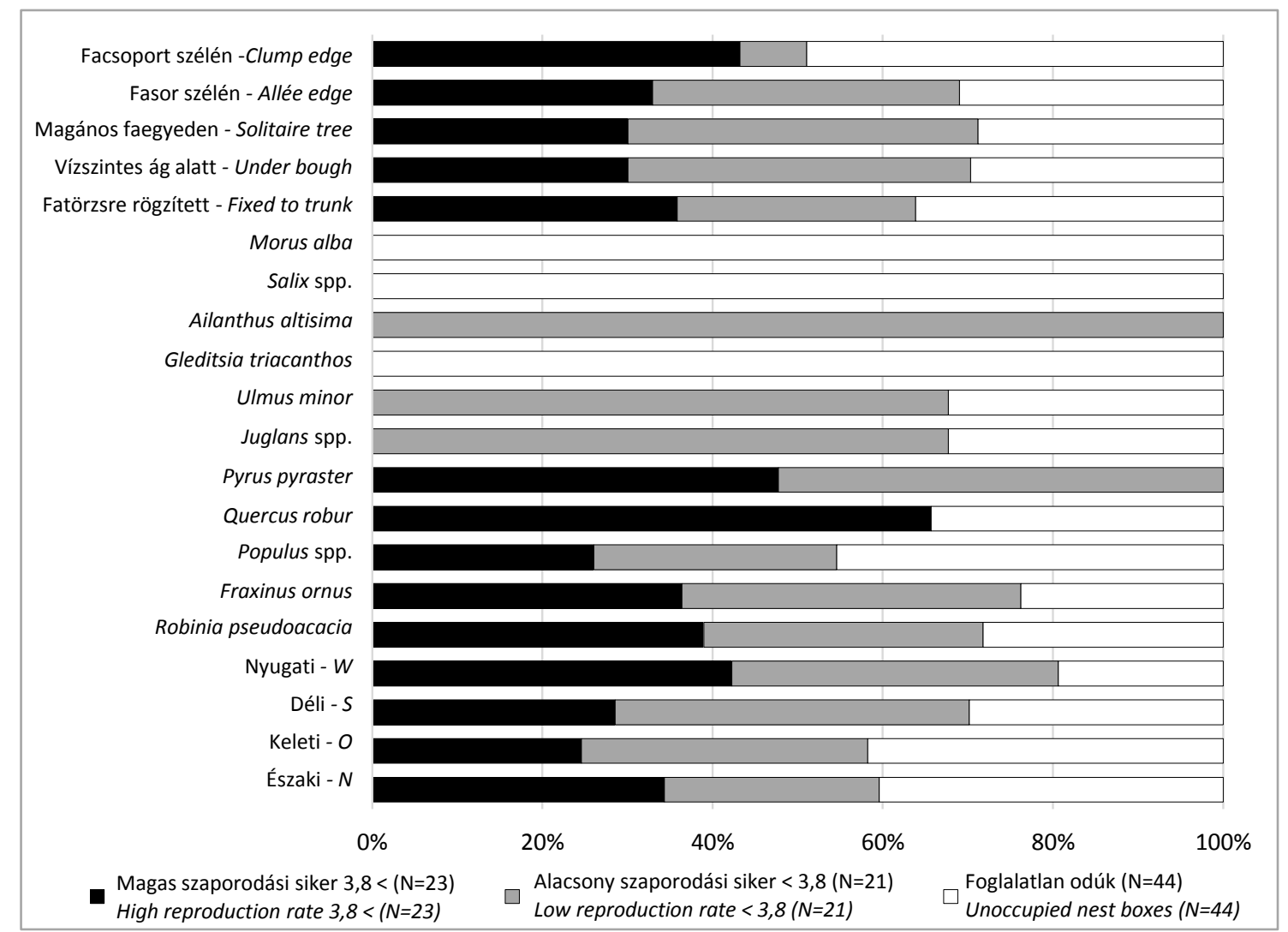

6. ábra: Magas és alacsony szaporodási siker-átlaggal rendelkező, valamint a foglalatlan odúk paramétereinek összevetése

Figure 6: Comparison of parameters of unoccupied nests with ones of high and low reproductive success 


\section{KONKLÚZIÓ}

Adott élőhelyen a fészkelési lehetőségek számának mesterséges növelése magasabb denzitást és területi költésszámot eredményezhet, amely ezen diszpergáló faj esetében a kirepült fiókák szétszóródását is elősegíti a környező élőhelyeken (KING \& BELTHOFF, 2001). Egyes tanulmányok (HölzINGER, 1987; EXO, 1992) arról számoltak be, hogy a költőládaszám növelésével idővel nem nőtt arányosan a költő párok száma. A vizsgálati időszak eredményei alapján a kiskunsági kuvikpopuláció viszont kimagasló reprodukciós eredményeket produkált a kihelyezett odúkban és e tekintetben további pozitív tendencia várható. A mesterséges odúk kihelyezése egy igen hatékony módszer a kuvikok védelmére, amely segítségével stabilizálni, hosszú távon növelni lehet egy csökkenő populációt. Az eredmények alapján lényeges, hogy a költőodúk telepítése kizárólag olyan helyeken történjen, ahol az élőhely a faj számára alkalmas és ahol valószínü, hogy fészkelése magas szaporodási sikerrel járhat. A költőodú hatékony elhelyezése révén kisebb ráfordítás mellett hosszútávon fenntartható az adott populáció, illetve a szakmailag előkészített, ellenőrzött és értékelt tevékenység megelőzheti, hogy egy adott élőhelyen az állomány lecsökkenjen a már kritikus egyedszámra. Azt találtuk, hogy az odú egyes paraméterei és az élőhelytípusok térbeli távolságai befolyásolhatják a foglalási rátát. A felső-kiskunsági eredmények alapján az öt éves vizsgálati időszak alatt a kuvikodú-foglaltságot és a szaporodási sikert az erdők távolsága, az aszfaltozott közutak távolsága, a legeltetett gyepterületek távolsága, valamint az odú láthatósága befolyásolja. Az odú berepülö nyílásának irányzéka, valamint a rögzítések között nem mutatkozott nagy különbség az értékelt esetekben. A megfogalmazott szempontok figyelembevételével a területre már kihelyezett, foglalatlan odúk áttelepítésével a védelmi tevékenység hatékonysága javítható. Fontos, hogy az ilyen projektek megkezdése előtt az adott élőhelyen megtörténjenek a terepi helyszíni és térinformatikai elemzések. Az értékes természetvédelmi eredmények ellenére a konzerváció-biológiai célkitűzéseknek a költőhelyek biztosítása céljából csak rövidtávon felelhet meg a mesterséges odútelepek létrehozása és kezelése. A faj eredendő élöhely-preferenciáinak és költésbiológiájának ismeretében a legfontosabb hosszú távú természetvédelmi célkitüzés az antropogén veszélyeztető tényezőktől mentes élőhelyek biztosítása és védelme. Ehhez viszont a faj számára megfelelő élöhelyeken aktuális természetvédelmi feladat a mesterséges fészekodúk kihelyezésével és biztosításával párhuzamosan a természetes költőhelyi lehetőségek megteremtése.

A vizsgálati téma kapcsán a jövőben további, részletes kutatások szükségesek a faj élőhelyi preferenciájának megértéséhez. Az odúkhoz tartozó paraméterek és az élőhelyi távolságok mellett elemezni kell a kuvik élőhelyi skáláiba (fészkelési terület, otthonterület, tájléptékü skála) tartozó élőhelyek szerkezetét, mozaikosságát, fragmentáltságát és megoszlását is.

\section{KÖSZÖNETNYILVÁNÍTÁS}

Hálásan köszönöm DR. WINKLER DÁNIEL ANDRÁS segítségét és útmutatásait, valamint a MAgYARORSZÁGi KUVIK OLTALMI EGYESÜLET tagjainak terepi munkáját és segítségét!

\section{IRODALOMJEGYZÉK}

Angelici, F. M., Latella, L., Luiselli, L. \& Riga, F. (1997): The summer diet of the Little Owl (Athene noctua) on the Island of Astipalaia (Dodecanese, Greece). Journal of Raptor Research 31: $280-282$. 
BIRDLIFE INTERNATIONAL (2015): Species factsheet: Athene noctua. Downloaded from http://www.birdlife.org on 31/05/2015

Bolton, M., Medeiros, R., Hothersall, B. \& CAmpos, A. (2004): The use of artificial breeding chambers as a conservation measure for cavity-nesting procellariiform seabirds: a case study of the Madeiran Storm Petrel (Oceanodroma castro). Biological Conservation 116: 73-80. http://dx.doi.org/10.1016/S0006-3207(03)00178-2

CRAMP, S. (1985): The Birds of the Western Palearctic. Vol. 4. Terns to Woodpeckers. Oxford, New York: Oxford University Press, 514-525.

Exo, K-M. \& HENNES, R. (1980): Beitrag zur Populationsökologie des Steinkauzes (Athene noctua). Vogelwelt 99: 137-141.

ExO, K-M. (1992): Population ecology of Little Owls Athene noctua in Central EuROPE: A review. In: Galbraith, C. A.; Taylor, I.R. \& Percival, S. (Eds.): The Ecology and Conservation of European Owls. Joint Nature Conservation Committee. UK Nature Conservation, No. 5. Petersborough, 64-75.

FRIAS, O. (1999): Estacionalidad de los atropellos de aves en el centro de Espana: numero y edad de los individuos y riqueza y diversidad de especies. Ardeola 46: 23-30.

GÉNOT, J-C. (1991): Mortalité de la Chouette chevêche, Athene noctua, en France. In: JUILLARD, M., BAssin, P., BAUdvin, H. (Eds.): Rapaces Nocturnes Actes du 30e colloque interrégional d'ornithologie Porrentruy (Suisse). November, 2-4, 1990. Nos Oiseaux, 139-148.

GÉNOT, J-C. (1992): Biologie de reproduction de la Chouette chevêche Athene noctua, en France. L'Oiseau et R.F.O. 62: 309-319.

GÉNOT, J-C. \& VAN NIEUWENHUYSE, D. (2002): Little Owl Athene noctua. BWP Update 4: 35-63.

GORMAN, G. (1995): The status of owls (Strigiformes) in Hungary. Buteo 7: 95-108.

GotTSCHALK, T.K., EKSCHMITT, K. \& WOLTERS, V. (2011): Efficient placement of nest-box for the little owl (Athene noctua). Journal of Raptor Research 45: 1-14. http://dx.doi.org/10.3356/JRR-09-11.1

HÁMORI D. (2009): A kuvik (Athene noctua (SCOP.) 1769) felmérése és védelme a FelsőKiskunságban. Nyugat-magyarországi Egyetem, Erdőmérnöki Kar.

HÁMORI D. (2012): Kuvikodú-telepítés szempontjai alföldi területeken. Heliaca 10: 61-63.

HÁMORI D. \& CsORTOS Cs. (2015): A Kuvik Munkacsoport 2015. évi beszámolója. Heliaca 13: 1517.

HÁMORI D. (2016): Antropogén fészkelö-helyekre kényszerült kuvik Athene noctua (Scopoli,1769) konzervációbiológiai lehetőségei a felső-kiskunságban. Erdészettudományi Közlemények 6(2): 175-187. http://dx.doi.org/10.17164/EK.2016.014

HARASZTHY L. (1982): Kuvik-odú készítése. Madártani Tájékoztató, okt.-dec.: 259-262.

HÖLZINGER, J. (1987): Vögel Baden-Württembergs. Volume 1: Gefährdung und Schutz - Steinkauz. Landesanstalt für Umweltschutz Baden-Württemberg, Karlsruhe, Germany.

Juillard, M. (1989): The decline of the Little Owl Athene noctua in Switzerland. In: MeYBURG, B.U. \& CHANCELOR, R. D. (Eds.): Raptors in the Modern World. Proceedings of the III. World Conference on Birds of Prey and Owls. Eilat, Israel, March 22-27, 1987. Berlin, London and Paris, 435-439.

KALOTÁS Zs. (1987): Adalékok a menyétféle ragadozók fészekalj pusztító tevékenységéhez és károsításaik megelőzéséhez. Madártani Tájékoztató, jan.-jún.,13-16.

KinG, R.A. \& BELTHOFF, J.R. (2001): Post-fledging dispersal of Burrowing Owls in southwestern Idaho: characteristics of movements and use of satellite burrows. Condor 103: 118-126. http://dx.doi.org/10.1650/0010-5422(2001)103[0118:PFDOBO]2.0.CO;2

KIRCHBERGER, K. (1988): Artenschutzmöglichkeiten beim Steinkauz und Schwarzmilan. Vogelschutz im Österreich 2: 52-55.

KISS, O., TOKODY, B., DEÁK, B. \& MOSKÁT, CS. (2016): Increased landscape heterogeneity supports the conservation of European rollers (Coracias garrulus) in southern Hungary. Journal for Nature Conservation 29: 97-104. http://dx.doi.org/10.1016/j.jnc.2015.12.003

Klein, Á., NAGY, T., CsÖRGÖ, T. \& MÁTICS, R. (2007): Exterior nest-boxes may negatively affect barn owl Tyto alba survival: an ecological trap. Bird Conservation International 17: 273-281. http://doi.org/10.1017/S0959270907000792 
LAmbrechts, M.M., Wiebe, K.L., Sunde, P. \& Solonen, T. (Eds.) (2012): Nest box design for the study of diurnal raptors and owls is still an overlooked point in ecological, evolutionary and conservation studies: a review. Journal of Ornithology 153(1): 23-34. http://doi.org/10.1007/s10336-011-0720-3

LECOMTE, P., LAPIOS, J-M. \& GÉNOT, J-C. (2001): Plan de restaruation des populations de Chevêches d'Athéna en France. In: GÉnOt, J.-C.; LAPIOS, J.-M.; LeCOMTE, P. AND Leigh, R. S. (Eds.)(2000): Chouette chevêche et territories. Actes du Colloque International de ChampsurMarne, November 25-26, ILOWG, Ciconia 25: 159-171.

LEIGH, R. (2001): The breeding dynamics of Little Owls (Athene noctua) in North West England. In: GÉNOT, J-C., LAPIOS, J-M., LeCOMTE, P. \& Leigh, R. S. (Eds.): Chouette chevêche et territories. Actes du Colloque International de Champsur-Marne, November 25-26, ILOWG, Ciconia 25: 67-76.

LOWTHER, P.E. (2012): Does nest-box size impact clutch size of house sparrows? Wilson Journal of Ornithology 124: 384-389.

MÄND, R., TILGAR, V., LÕHMUS, A. \& LEIVITS, A. (2005): Providing nest boxes for hole-nesting birds - does habitat matter? Biodiversity Conservation 14:1823-1840. http://doi.org/10.1007/s10531-004-1039-7

MAYFIELS, H. F. (1961): Nesting success calculated from exposure. Wilson Bulletin 73: 255-261.

MiKKOLA, H. \& WILLIS, I. (1983): Owls of europe. Vermillion, SD USA: Buteo Books.

MME NOMENClATOR BizOTTSÁG (2008): Nomenclator Avium Hungariae. Magyarország madarainak névjegyzéke. MME, Budapest.

NewTON, I. (1994): The role of nest sites in limiting the numbers of hole-nesting birds: a review. Biodiversity Conservation 70: 265-276. http://dx.doi.org/10.1016/0006-3207(94)90172-4

OlAH, G., Vigo, G., HeInsohnA, R. \& BRIGHTSMITH, D. J. (2014): Nest site selection and efficacy of artificial nests for breeding success of Scarlet Macaws Ara macao macao in lowland Peru. Journal for Nature Conservation 22: 176-185. http://dx.doi.org/10.1016/j.jnc.2013.11.003

PRIDDEl, D., CARLILE, N. \& WhEeler, R. (2006): Establishment of a new breeding colony of Gould's Petrel (Pterodroma leucoptera leucoptera) through the creation of artificial nesting habitat and the translocation of nestlings. Biological Conservation 128: 553-563. http://dx.doi.org/10.1016/j.biocon.2005.10.023

RAKONCZAY Z., TÖLGYESI I. \& VAJDA Z. (2001): A Kiskunságtól Bácsalmásig: a kiskunság természeti értékei. Mezőgazda Kiadó, Budapest.

ROBERTSON, B.A. \& HUTTO, R.L. (2006): A framework for understanding ecological traps and an evaluation of existing evidence. Ecology 87: 1075-1095. http://dx.doi.org/10.1890/0012-9658(2006)87[1075:AFFUET]2.0.CO;2

ŠÁLEK, M. \& LÖVY, M. (2012): Spatial ecology and habitat selection of Little Owl Athene noctua during the breeding season in Central European farmland. Bird Conservation International 22(03): 328-338. http://dx.doi.org/10.1017/S0959270911000268

ŠÁleK, M., Chrenkova, M. \& KIPSON, M. (2013): High population density of Little Owl (Athene noctua) in Hortobagy National Park, Hungary, Central Europe. Polish Journal of Ecology 61: $165-169$.

SCHMIDT E. (1998): Kuvik. In: HARASZTHY L. (szerk): Magyarország madarai. Mezőgazda Kiadó, Budapest, 218-219.

SCHÖNN, S., ScherzINGER, W., Exo, K-M. \& ILle, R. (1991): Der Steinkauz. Die Neue BrehmBücherei. Wittenberg Lutherstadt. A. Ziemsen Verlag.

SCHWARZENBERG, L. (1970): Hilfe unserem Steinkauz. DBV Jahresheft, 20-23.

STANDOVÁR T. \& PRIMACK R.B. (2001): A természetvédelmi biológia alapjai. Nemzeti Tankönyvkiadó.

Sutherland, W.J., NEWTON, I. \& GREEN, R.E. (2004): Bird ecology and conservation. Oxford University Press, New York.

ThoruP, K., Sunde, P., JACOBSEN, L.B. \& RAHBEK, C. (2010): Breeding season food limitation drives population decline of the Little Owl Athene noctua in Denmark. Ibis 152(4): 803-814. http://dx.doi.org/10.1111/j.1474-919X.2010.01046.x 
TOMÉ, R., BloISE, C. \& KORPIMÄKI, E. (2004): Nest-site selection and nesting success of Little Owls (Athene noctua) in Mediterranean woodland and open habitats. Journal of Raptor Research 38: $35-46$.

VAn NieuwehuYse, D., LeYSEn, M. \& SteEnhoudt, K. (2001): Analysis and spatial prediction of Little Owl Athene noctua distribution in relation to its living environment in Flanders. Oriolus 67: $32-51$.

VAn Nieuwenhuyse, D., GÉnot, J-C. \& Johnson, D.H. (2008): The Little Owl: Conservation, Ecology and Behavior of Athene noctua. Cambridge University Press, The Edinburgh Building, Shaftesbury Road Cambridge CB 22 RU UK.

Zabala, J., Zuberogoitia, I., MartíneZ-Climent, J.A., Martínez, J.E., AZKona, A., Hidalgo, S. \& IRAETA, A. (2006): Occupancy and abundance of Little Owl (Athene noctua) in an intensively managed forest area in Biscay. Ornis Fennica 83(3): 97-107.

Zuberogoitia I., MARTineZ J. A., ZABALA J. \& MARTíNEZ J. E. (2005): Interspecific aggression and nest-site competition in a European owl community. Journal of Raptor Research 39: 156-159. 